and one man), but appearances were normal. An automatic film changer was used, however, and Burden et al found this unsatisfactory for recognising fine detail. Hence minor abnormalities may have been missed in our patients.

Failure to realise that recurrent haematuria may result from renal lesions diagnosable only by microscopy led to formidable over-investigation in some of these patients. Table II gives details of five young women who underwent frequent admissions to hospital and repeated radiological investigation. One woman was in hospital for 579 days over three and a half years $(68 \%$ of the total time), and exposure to diagnostic irradiation was enough to necessitate the termination of a mid-trimester pregnancy. One patient had a kidney removed, only for pain to occur for the first time in the other loin within days of the operation. Another woman underwent polar nephrectomy. The kidney substance and vasculature removed in both these patients was histologically normal. A psychogenic and artefactural basis for their complaints was suspected at some time in each of these five women and three had received intensive psychiatric assessment. Possibly the prolonged uncertainty and length of stay in hospital before a firm diagnosis was made were contributing factors. Neither pain nor haematuria has recurred in cases 32 and 33 for 54 and 23 months respectively after firm reassurance and the end of investigation. Even when renal biopsy discloses a lesion for which specific treatment is not available the establishment of a diagnosis prevents unnecessary further investigation, may allow a prognosis to be given, and facilitates management.

\section{References}

1 O'Reilly, P H, Postgraduate Medical fournal, 1974, 50, 746.

2 Burkholder, G V, et al, Fournal of the American Medical Association, 1969, 210, 1729.

${ }^{3}$ British Medical fournal, 1975, 1, 647.

4 Davies, D R, et al, fournal of Clinical Pathology, 1973, 26, 672.

${ }^{5}$ Chen, B T M, et al, Quarterly fournal of Medicine, 1972, 41, 141.

${ }^{6}$ Hendler, E D, Kashgarian, M, and Hayslett, J, Lancet, 1972, 1, 458.

7 Alexander, F, Lannigan, R, and Bull, R, fournal of Clinical Pathology, 1973, 26, 750.

${ }^{8}$ Van de Putte, L B A, de la Riveire, G B, and Van Breda Vriesman, P J C, New England fournal of Medicine, 1974, 290, 1165.

${ }^{9}$ Berger, J, Transplantation Proceedings, 1969, 1, 939.

10 Werra, P de, et al, Schweizerische medizinische Wochenschrift, 1973, 103, 761.

11 Evans, D J, et al, British Medical fournal, 1973, 3, 326.

12 Morel-Maroger, L J, and Verroust, P J, in Recent Advances in Renal Disease, ed N F Jones, chap 2, p 76. London, Churchill Livingstone, 1975.

13 Burden, R P, et al, Quarterly fournal of Medicine, 1975, 44, 433.

${ }_{14}$ Little, P J, Sloper, J S, and De Wardener, H E, Quarterly fournal of Medicine, 1967, 36, 253.

\title{
Rapid glucose absorption in Arabs in Saudi Arabia compared with that in Africans in Zambia
}

\author{
G C COOK
}

British Medical fournal, 1976, 1, 688-689

\section{Summary}

Glucose absorption rates in 14 Arabs in Saudi Arabia were determined by a jejunal perfusion technique and compared with those in 18 Africans in Zambia. None of the subjects had clinical evidence of systemic infection, gastrointestinal disease, malnutrition, or diabetes mellitus. The mean absorption rate was significantly higher in the Arabs. This was associated with a higher incidence of subclinical chronic systemic infection in the Africans. Other factors possibly responsible for the difference, including genetic differences, have, however, not been excluded.

\section{Introduction}

A low jejunal absorption rate of glucose in the presence of high serum $\gamma$-globulin ${ }^{1}$ and IgG $^{2}$ concentrations (probably related to subclinical or inadequately treated infections, especially malaria and schistosomiasis) has been shown in Zambian Africans without clinical evidence of a systemic infection. The glucose absorption rate of Arabs in Saudi Arabia has been determined using the same technique; chronic systemic infections are

\footnotetext{
Department of Medicine, University of Riyadh, Riyadh, Saudi Arabia

G C COOK, MD, FRCP, professor of medicine (present address: Medical Unit, Hospital for Tropical Diseases, London NW1 OPE)
}

uncommon in Riyadh, but schistosomiasis and occasionally malaria occur in Yemeni immigrants.

\section{Subjects and methods}

Fourteen patients (four Bedouin, four urban Saudis living in Riyadh, one Iraqi, and five Yemenis) were studied at the King Abdul Aziz Hospital, Riyadh, after giving their informed consent through an interpreter. They had minor diseases and none had clinical evidence of systemic infection, gastrointestinal disease, malnutrition, or diabetes mellitus. Thirteen were men. Mean age was 25 (16-39) years and mean body weight $54(40-76) \mathrm{kg}$. None was clinically anaemic; in six the mean haemoglobin was $12 \cdot 2(11 \cdot 0-13 \cdot 0) \mathrm{g} / \mathrm{dl}$. Stools from five patients were examined for parasites; one contained a few ova of Schistosoma mansoni. Serum proteins were determined as described, $\mathbf{1}$ except that the standard was Seronorm (batch 122) (Nyegaard, Norway). Mean serum albumin concentration was $38(28-44) \mathrm{g} / \mathrm{l}$, and mean $\alpha_{1^{-}}, \alpha_{2}{ }^{-}, \beta-$, and $\gamma$-globulins were $3(2-6) \mathrm{g} / 1,9(6-14) \mathrm{g} / \mathrm{l}, 8$ (6-11) $\mathrm{g} / \mathrm{l}$, and $16(11-24) \mathrm{g} / \mathrm{l}$ respectively. In 10 patients the mean five-hour xylose excretion after a 25 -g oral load ${ }^{1}$ was $47(34-62) \mathrm{mmol}[7 \cdot 0(5 \cdot 13-$ $9.31) \mathrm{g}]$; the mean blood xylose concentration at 90 minutes was $3 \cdot 3(2 \cdot 4-5 \cdot 8) \mathrm{mmol} / \mathrm{l}[50(36-87) \mathrm{mg} / 100 \mathrm{ml}]$.

The glucose absorption rate from a $0 \cdot 2 \mathrm{M}$ glucose solution (which also contained $100 \mathrm{mmol} \mathrm{NaCl}$ and $5 \mathrm{~g}$ polyethylene glycol 4000 per l) was determined for a $30-\mathrm{cm}$ jejunal segment ${ }^{1}$; constant-flow pump, double-lumen perfusion tube (and mercury weight), etc were identical with those used in Zambia, ${ }^{13}$ but glucose was determined by a hexokinase method (Boehringer Mannheim, 15931). The mean distance of the proximal opening of the tube past the duodenojejunal flexure was $9(1-24) \mathrm{cm}$. Reproducibility of the glucose absorption rate ${ }^{4}$ was: mean 1.68 (SD 0.10$) \mathrm{mmol} / \mathrm{min}[0.302$ (SD 0.019) $\mathrm{g} / \mathrm{min}]$; coefficient of variation $=6.3 \%$.

Two additional men with chronic liver disease and portal hypertension were studied. $S$ haematobium and $S$ mansoni were found in their stools, and aspiration liver biopsy in the first showed cirrhosis. Serum albumin concentrations were $34 \mathrm{~g} / \mathrm{l}$ in the first and $28 \mathrm{~g} / \mathrm{l}$ in the second man, and $\gamma$-globulin concentrations were 27 and $25 \mathrm{~g} / 1$ respectively. 


\section{Results}

The figure summarises results for the Arabs and Africans. ${ }^{1}$ For all results $(t=4.07 ; \mathrm{DF}=30 ; \mathrm{P}<0.001)$, and also when the perfusion segment was proximal $(t=2.72 ; \mathrm{DF}=22 ; \mathrm{P}<0.02)$, the difference was significant (Student's $t$ test). Mean net water absorption rate in the Arabs was $4.49(2.30-7.44) \mathrm{ml} / 30 \mathrm{~cm}$ of jejunum/min and in the Africans $1.88(-1.15-4.72) \mathrm{ml} / 30 \mathrm{~cm}$ of jejunum $/ \mathrm{min}$; this difference was significant $(t=4.99 ; \mathrm{DF}=30 ; \mathrm{P}<0.001)$.

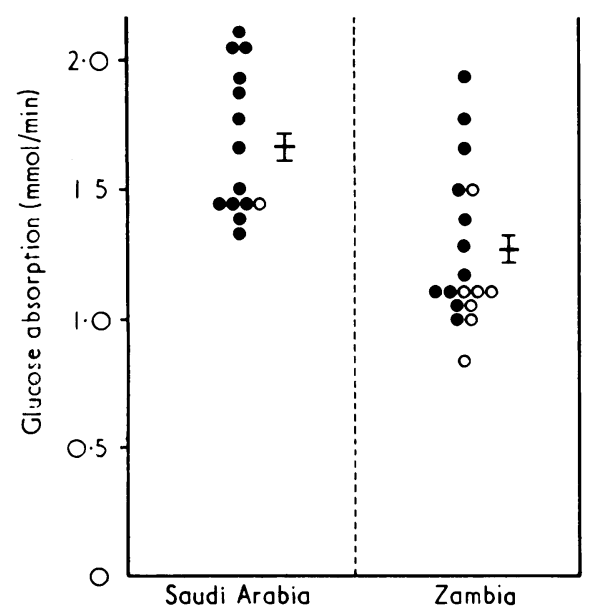

Glucose absorption rates ( $\mathrm{mmol} / 30 \mathrm{~cm}$ jejunum $/ \mathrm{min})$. Means $( \pm S E$ of mean) are indicated. $=$ Infusion $\leqslant 20 \mathrm{~cm}$ past duodenojejunal flexure. $O=$ Infusion $>20 \mathrm{~cm}$ past duodenojejunal flexure.

In the Arabs the correlation between glucose absorption rate and age, body weight, and serum albumin and globulin fractions was not significant, and absorption rates were distributed fairly evenly between the various nationalities. The correlation between glucose and water absorption rates was significant $(r=0.77 ; D F=12$; $\mathrm{P}<0.01$ )

Mean serum $\gamma$-globulin concentration was significantly lower in the Arabs than in the Africans ${ }^{1}(t=3.05 ; \mathrm{DF}=30 ; \mathrm{P}<0.005)$, but mean serum albumin and $\alpha_{1^{-}}, \alpha_{2^{-}}$, and $\beta$-globulins were not significantly different.

In the additional two men glucose absorption rates were $0.22 \mathrm{mmol} /$ $\min [0.04 \mathrm{~g} / \mathrm{min}]$ in the first patient, and $1.22 \mathrm{mmol} / \mathrm{min}[0.22 \mathrm{~g} / \mathrm{min}]$ in the second patient.

\section{Discussion}

Rapid glucose absorption in the Arabs seems most likely to have been related to the lower incidence of subclinical systemic infection ${ }^{12}{ }^{5}$; mean serum $\gamma$-globulin was the only index that was significantly different from the findings in the Africans. The difference was not due to subclinical malnutrition in the Africans, ${ }^{\circ}$ and, although not studied in the Arabs, jejunal morphology seems unlikely to be relevant. ${ }^{7}$ Genetic factors have not been excluded.

Maturity onset diabetes mellitus and impaired glucose tolerance are common in Arabs in Riyadh; they are not usually associated with obesity (G C Cook, unpublished). Much refined sucrose is taken throughout the day, usually in tea; mucosal hydrolysis of sucrose is not rate-limiting in its absorption. ${ }^{8}$ Impaired glucose tolerance might therefore be due to pancreatic $\beta$-cell stress associated with repeated portal hyperglycaemia. ${ }^{9}$ Africans in Lusaka now consume refined sucrose in addition to their staple carbohydrate diet, but impaired glucose tolerance and maturity onset diabetes are relatively uncommon ( $\mathrm{G} C$ Cook, unpublished); their slower glucose absorption presumably prevents excessive insulin secretion. Systemic infections may partly explain, therefore, the apparent rarity of diabetes and impaired glucose tolerance in Africans in Africa.

I thank Dr M T Al-Torki for explaining the procedure to the patients.

\section{References}

1 Cook, G C, Nature, 1973, 241, 284.

2 Cook, G C, British Medical fournal, 1974, 4, 200.

3 Cook, G C, and Carruthers, R H, Gut, 1974, 15, 545.

4 Cook, G C, Clinical Science, 1972, 42, 525.

5 Cook, G C, and Lewis, K O, Tropical and Geographical Medicine, 1975, 27, 185.

6 Cook, G C, British fournal of Nutrition, 1974, 32, 503.

7 Cook, G C, Gut, 1974, 15, 239.

${ }^{8}$ Gray, G M, and Ingelfinger, F J, Fournal of Clinical Investigation, 1966, 45, 388.

9 West, K M, Nutrition Reviews, 1975, 33, 193.

\section{SHORT REPORTS}

\section{Portal hypertension in Waldenström's macroglobulinaemia}

Intrahepatic presinusoidal portal hypertension and bleeding oesophageal varices due to Waldenström's macroglobulinaemia occurred in one of our patients.

\section{Case report}

A 60-year-old man, admitted as an emergency with acute retention of urine and benign prostatic hypertrophy, was seen with an additional complain of upper gastrointestinal bleeding. He had vomited $570 / \mathrm{ml}$ of altered blood and passed two malaena stools on the day before admission. Bleeding continued for four days. He admitted to ill health in the previous two months, with $5 \mathrm{~kg}$ weight loss, increasing breathlessness on exertion, and ankle swelling. For 40 years he had suffered from psoriasis, at one time treated with methotrexate, but more recently controlled by local steroid applications. During this illness he had iritis and an arthropathy of the knees and ankles, for which he was receiving indomethacin. He was wasted, anaemic, and had extensive psoriasis. Enlarged, fleshy lymph nodes were felt in the axillae and groins, and there was moderate firm hepatosplenomegaly. Initial haematological investigation showed haemoglobin $3.6 \mathrm{~g} / \mathrm{dl}$, white blood count $5 \times 10^{9} / 1\left(5000 / \mathrm{mm}^{3}\right)$, platelets $150 \times 10^{9} / 1\left(150000 / \mathrm{mm}^{3}\right)$, and the blood film showed definite rouleaux formation. The erythrocyte sedimentation rate (Westergren) was greater than $140 \mathrm{~mm}$ in $1 \mathrm{~h}$. Total serum protein concentration was $87 \mathrm{~g} / \mathrm{l}$, with albumin $36 \mathrm{~g} / \mathrm{l}$, and gammaglobulin raised at $37 \mathrm{~g} / 1$. This last fraction contained a wide fast-moving paraprotein band. The bone marrow aspirate was hypercellular owing to a heavy infiltration with lymphocytoid and plasma cells, both erythropoiesis and leucopoiesis being depressed. Immunofluorescent staining showed an IgM kappa monoclone of plasma cells predominating. Waldenström's macroglobulinaemia was diagnosed. Uncorrected whole blood viscosity at two rates of shear was normal. The only coagulation abnormality was a minor increase in prothrombin time to $14.5 \mathrm{~s}$ against a control of $12 \mathrm{~s}$. A 24-hour urine specimen contained $1.5 \mathrm{~g}$ protein, but Bence Jones protein was not detected. At gastroscopy oesophageal varices with an overlying erosion were seen. No peptic ulcer was found either at this examination or on barium studies.

Initial liver function tests showed a mildly raised bilirubin (which did not persist), but normal transaminases and alkaline phosphatase. The remarkable feature on liver biopsy (fig) was the heavy infiltration of the portal tracts with lymphocytoid cells of the type present in the bone marrow; the parenchymal cells and liver architecture being normal.Trans-splenic portal venography showed the portal vein to be patent and demonstrated the oesophageal varices. At puncture the intrasplenic pressure was $20 \mathrm{~mm} \mathrm{Hg}$. A hepatic 